\title{
The Orang-utan and Rhinoceros in North Sumatra
}

\section{By OLIVER MILTON}

Between January and March, 1963, Oliver Milton made a twomonth survey of the status of the orang-utan and the Sumatran rhinoceros in North Sumatra, one of the few remaining areas in which these persecuted animals are to be found. He concluded that there were not more than 1,500 orang-utans and possibly as few as $\mathbf{8 0 0}$, and perhaps twenty Sumatran rhinoceros, all mainly, if not entirely, in the Loser Reserve. Indiscriminate smuggling by poachers with firearms he found to be the main threat to both animals. The survey, which was the first phase of a one-year project to study the status of the two animals in Indonesia, was sponsored by the Survival Service Commission of IUCN, with a generous grant from the World Wildlife Fund, and made with the permission of the Indonesian Government and the help of the local government officers.

THE Loser Reserve covers about 1,700 square miles and forms part of the great mountainous mass of unexplored primeval jungle in south-west Atjeh. The highest point of the complex is Gunong Loser (about 11,300 feet) at the north end of the Reserve. From the whole range, which decreases in height as it runs north-west-south-east, numerous streams flow westwards into the Indian Ocean and eastwards into the torrential Alas river. A very rough road runs parallel to the east bank of the Alas river and beyond this the Sorbolangit Range of densely forested mountains rises abruptly.

Kotajane, 135 miles from Medan, is a small town lying between these two mountain ranges and approximately level with their midway point. Although the road actually continues as far as Blangkerjeren the surface deteriorates to such an extent that trucks and buses stop at Kotajane. Further travel has to be by jeep, and even these vehicles find difficulty in covering the remaining sixty-five miles without getting bogged down in the mud or suffering serious mechanical trouble.

The boundary of North Sumatra and Atjeh is at Lau Pakam, about twenty-five miles south of Kotajane and here there is a police inspection post. Between here and Kotajane the populated areas decrease rapidly, except in the immediate vicinity of Kotajane where there is a string of small villages on comparatively flat ground and most of the land is cultivated for the production of coffee and marketable fruits such as durian, mangosteens, and oranges. Between Kotajane and Palok, five miles from Blangkerjeren, the land is almost uninhabited.

In 1937, Dr. C. R. Carpenter spent about a month studying the wildlife in the northern State of Atjeh, paying particular attention to the status of the orang-utan and the rhinoceros. Although he covered much of the area he apparently did not have enough time to investigate the Gajo and Alas 


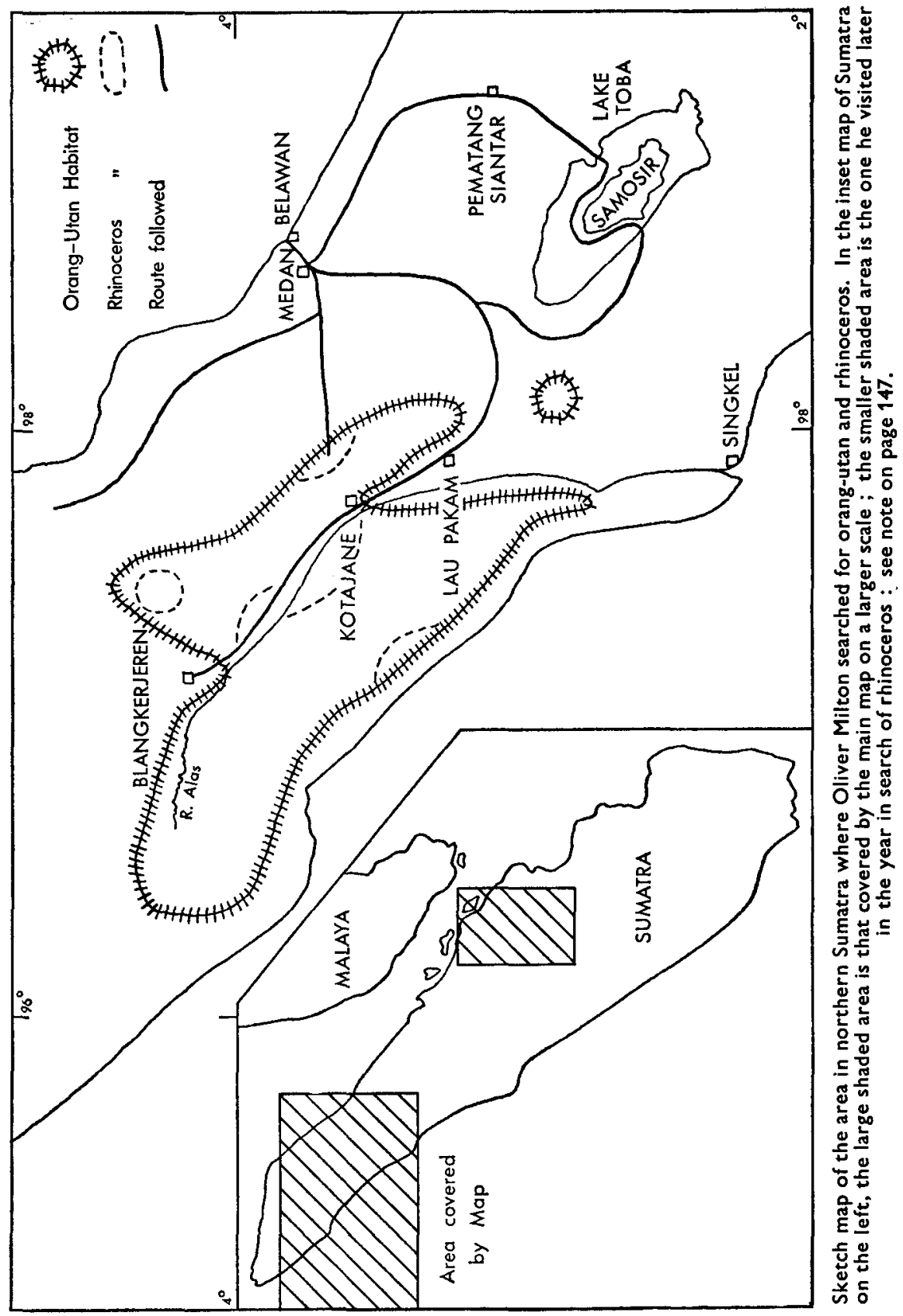


areas near the vast and almost unknown Loser Reserve, and so I made these two districts the object of my first field trip. My second excursion was in the vicinity of Lake Toba and I ended Phase 1 by visiting the north-east coastal areas near Kuala Simpang and the mountainous region to the west of Medan near Bukit Lawang.

\section{Plan of Campaign}

The plan was, starting from Kotajane, to work northwards along the Alas river camping at suitable spots en route, eventually reaching Blangkerjeren. From here, depending on local information available, I hoped to visit the regions to the north-west, north, and north-east, where both rhinoceros and orang-utan are reported to exist. In the event I did not get beyond Blangkerjeren from where I returned to Medan via Kotajane. Because of the distances covered much of the travelling was done by local bus or jeep. The buses are not too comfortable but they are cheap and eventually arrive at their destination in spite of inevitable breakdowns. Mr. W. Sinurat, who is the acting head of the section of the Forest Department concerned with the protection of wildlife in North Sumatra and Atjeh, accompanied me throughout the whole of Phase 1 and I am deeply indebted to him for his valuable assistance. At Kotajane, in Atjeh, Mr. Nasution, the Forest Officer, offered us hospitality and procured for me the services of a guide, Amansar, who, in turn, was able to procure the porters to carry my equipment.

Since Dr. Carpenter's visit in 1937 there have been inevitable changes both to the habitat and the conditions under which the mawas (the orangutans) have to live. Two main changes are, first, the cutting down of forested areas and the opening up of land for rural development and cultivation and, second, the ruthless poaching with firearms and motor transport. This poaching, which has increased seriously during the past twenty-five years, is far the more serious problem. Yet I am sure that it could be reduced if sufficiently strong action were taken by the appropriate authorities.

The people recognize three types of orang-utan: mawas kuda (horse mawas), which has little if any marketable value as it is usually an old lone male of considerable size and weight; mawas kambing (goat mawas), which is very acceptable and weighs up to $100 \mathrm{lb}$.; mawas perok (squirrel mawas), which is the smallest and ranges up to about $50 \mathrm{lb}$. Incidentally, the people quite frequently refer to the siamang (Hylobates syndactylus), the largest of the gibbons, as the mawas hitam, black mawas.

\section{The Desirable Ages}

Mawas weighing about $20 \mathrm{lb}$, or about one year old, are the most sought after. Larger than this they are harder to catch and more difficult to keep in captivity and hide from the authorities during the trip to the coast. Very young ones are merely hidden under the owner's coat. But the usual practice is to squeeze two or more into a small box which is then placed on a bus or jeep and sent to Medan.

Because of the terrain the only practicable method by which mawas can be exported from central Atjeh is by road through Kotajane. The 
various check posts en route cause little trouble because a large sum of money passes hands " under the counter". On arrival in Medan the illegal owner keeps the mawas in a secluded spot some distance from his own house, and when the necessary arrangements have been completed the animal(s) are sent to Belawan where they are stowed on board one of the many boats going to Singapore or the Malayan ports or elsewhere. Mawas caught further north are sent from other smaller ports.

There are two distinct methods of capture. If firearms are used, a female is shot and the young taken. Hunters without guns first locate a mawas in a tree; they then fell the surrounding trees, leaving the animal isolated. When it has eaten everything-leaves, fruit, and barkand is suffering from thirst, the unfortunate animal is forced to the ground. The men dash out, two of them grabbing an arm each while one takes hold of the back of the head. The arms are tied behind the back and the animal is thrust into a sack and removed.

\section{Conditions in Captivity}

After capture the animal is given almost no attention. It is looked on as a source of money and there is no thought of showing it any kindness. I saw nine mawas in captivity, in addition to six in the zoo at Pemangsiantar, and nearly all of them were imprisoned in a wooden box or crate of such a size that it was impossible for the animal to stand up. In two instances there were two animals in a box so small that they had to spend the whole time in a crouched position with their arms around each other. Another mawas which stood about 3 feet high spent the whole time on a wooden shelf in a cage which measured about 9 feet high and 3 feet square with the front enclosed by 1-inch iron bars. They are nearly all fed on boiled rice, bananas, and perhaps some pineapple; with this unnatural diet their stomachs become very distended and, unable to move or keep clean, they become sick and as often as not die. I also saw one siamang that was kept tied on a short rope in a garage. This smelt of oil, petrol, and urine from the adjacent house and the poor animal could walk nowhere except on the oily floor or the smooth drums.

There appear to be two values for the mawas. Somebody who has happened to find one and captured it will probably accept about 10,000 rupiah, which is about U.S. $\$ 230$ at the official rate. But a hunter who went specially to get one, and had been away for a week or longer, would want in Kotajane about 17,000 rupiah and in Medan about 24,000 rupiah. Several years ago a young mawas might have fetched as much as 37,000 rupiah, and it is encouraging that the prices are decreasing. This is because the wildlife conservation authorities have been confiscating illegally owned mawas, and people are slowly becoming less anxious to trade in these animals. But there is still a lot to be done to stop the trade completely.

The authorities estimated that during 1961-62 no fewer than 280 orangutans were sent through Kotajane to Medan. On arrival many were dead owing to bad handling and the criminally small boxes in which the animals were kept. One of my porters claimed to have caught eight himself between October and December last year. 
It is not possible to give an exact figure of the number of mawas in captivity as it varies daily, but at the beginning of March, 1963, no fewer than forty-seven mawas could be accounted for in south Atjeh and in the general vicinity of Medan. In addition to these three more are known to have died recently and the corpse of one of these was found by two of my porters on 6th February near Meleuwak. It was a largish animal with a rope around its neck and lying on the edge of the river partially decomposed.

\section{Mawas on a Nest}

In the wild north of Kotajane, I was only fortunate in seeing mawas on three occasions; once a lone male, and twice a family group of three. The first time, at Aunan, we had packed our belongings and were on the point of moving camp when a man hurried to tell us that he had just seen a mawas further up the road. We hastened to the spot, which was about $\mathbf{1 0 0}$ yards from the road on the edge of a small rubber plantation. I had some difficulty in seeing the animal even though it was asleep on a nest about 50 feet from me. With the binoculars, however, I could make out a patch of reddish hair which protruded over the rim of the mass of twigs and sticks that formed the crude sleeping place. The nest was about 30 feet from the ground in a small tree. As I watched from below I could see an arm (or leg) hanging over the side of the nest and holding on to a branch. One of the men started to climb a nearby tree and this woke the animal. It walked from its nest along a small branch to an adjoining leafless tree, remained there about a minute, examining us, and then urinated before moving to another tree. To manouvre a gap of about 4 feet it reached out with a foot, grabbed the tip of a branch and pulled it close so that it formed a bridge. Meanwhile the men had spotted a female with a baby in a tree about 60 feet away. The male approached her, moving through very thick foliage, and they all disappeared into the dense canopy. The colour of each was reddish, and the male had rather an obviously brownish face with a small beard.

\section{The Family Party}

The second one I saw, from the road north of Rumah Bandar, near Kungke, was a huge animal in the fork of a tall, almost leafless tree, about 300 yards away. It had two large cheek growths, a handsome beard, and the whole body appeared covered in long red hair that reminded me of Spanish moss. It was feeding in a leisurely way on the few leaves available and also the flowers of the tree, Zanthoxylum rhetsa, and finally settled down again in the fork of the tree and seemed to go to sleep.

The third occasion, again north of Rumah Bandar, I was walking some way ahead of the porters. At one point the branches of a huge fig tree were almost overhanging the path, and I saw, much to my surprise, a mawas walking upside-down along a branch, and then a second animal. The guide and I cut a path through the very dense undergrowth to the base of the tree and with some difficulty we could see one mawas on a nest in a fork overhead. We called out and tapped the tree, and suddenly a youngster of about a year (?) climbed out of the nest, walked and swung 
its way to the top of the tree, crossed to another by brachiating along a vine directly overhead and disappeared into the foliage. Eventually the other one on the nest (probably the mother) climbed out, walked up a thick branch, swung to another tree, and then brachiated along the same overhead vine. Half-way across it stopped to look down at us during which time it was suspended by one arm only. For several minutes both the adult and young were lost to sight but when they reappeared they were accompanied by a second adult, possibly the male. All these mawas were within a few hundred feet of the main track which is used by jeeps. In the jungle itself, far from the track, I saw numerous nests but no orang-utans.

I did not see any nests being constructed but saw two mawas on their nests at quite close quarters. Nests were usually built between 30 and 70 feet up, and this corresponds with the observations made by Schaller in Sarawak. Most were found up to an altitude of 3,000 feet although one was noted at 4,350 feet. The guide reported that they were to be found a little higher, possibly to a maximum of 5,000 feet.

\section{Estimating the Numbers}

The method adopted by Schaller and Mrs. Harrisson in Sarawak and North Borneo to reach a rough estimate of the population density of mawas in an area of known size consists of counting the number of nests seen, say within 100 feet on either side of the path, and dividing this by the number of hours (or miles at one mile per hour). It has been assumed that mawas build one nest a day and that each one remains visible for about six months. One mawas would therefore be considered responsible for 180 nests in one square mile.

However, my guide informed me that a nest only remained visible for about four months and that definitely more than one nest a day was constructed.

In the Alas and Gajo areas their range is known to extend from Lau Pakam to Blangkerjeren on either side of the Alas river. Except in a few places the jungle comes down to the river and the contours rise steeply on either bank. Bearing in mind that mawas are probably not naturally inclined to go above 5,000 feet, their range in this particular area could easily extend for ten miles on either side of the river and would therefore enclose an area of about 1,500 square miles. My estimates indicated one orang-utan per square mile but this was based on one nest per day, making an approximate total of 1,500 orang-utans in this particular area. However, I would prefer to halve this number on the basis of at least two nests per day and the fact that the nests are reported to last only four months.

Therefore I suggest that there might be 800 orang-utans in the area in question. In addition, however, there is an area to the north which I was unable to visit, another area on the coast on the west slopes of the Loser, and a third area directly west of Medan, all of which are known to contain orang-utan. Whatever their numbers might be the total population is dangerously low-perhaps 1,500 or a few more or less. If 280 animals are known to have been smuggled out in two years-and this does not include all the ones that have certainly died-at the end of ten years there may be 
none left unless some very strong and active steps are taken now. I do not believe there are any groups of any material size in Atjeh and North Sumatra east of an approximate line from Singkol to Pangkalan Brandan.

\section{Reluctance to Talk}

Compared with the amount of information I was able to gather about the orang-utan I unfortunately learnt little about the status of the rhinoceros. The average native knew practically nothing about their whereabouts, and I had to depend for my information on those few persons who had hunted illegally, and were therefore rather reluctant to divulge their secrets for fear of being arrested. In Blangkerjeren I had hoped to learn a lot from one man who is reputed to be the rhino expert of the whole area, but it soon became apparent that he was not prepared to give away any information that might incriminate himself. From other sources I learnt that this man had set up traps, and with other persons was engaged in smuggling horn.

In spite of the poaching, reports indicated that there are still rhino in quite a number of places in Atjeh. Nine specific places were mentioned to me and at one of these I was able to identify some old tracks near a salt lick. If there are rhino in all the mentioned places and if one estimated one family in each, say, three animals, the population is about thirty beasts. However, in at least three of the localities they are reported as being "frequent" or "by no means uncommon", and as almost nothing is known about their status in the main Loser Reserve, perhaps there is a population of double, or say fifty. Their numbers are by no means safe, and I was told that between 1942 and 1959 at least twenty had been shot or trapped.

The price of the horn seems to vary considerably. The lowest price was quoted as 9,000 rupiah per ounce (official rate of exchange U.S. \$1 equals 44 rupiah; black market about 1,000 rupiah). The highest price was 42,000 rupiah per ounce; this was about three years ago.

\section{CONCLUSIONS AND RECOMMENDATIONS}

In Atjeh and North Sumatra, as the Loser complex constitutes the main habitat area of the orang-utan and rhinoceros (excepting a smaller area to the north towards Lesten and Lokop, about which I received reports but did not visit), I suggest that an appropriate part of this magnificent natural mountainous area be selected as a special reserve for orang-utan and rhinoceros as soon as possible, but as-

(a) at the present time I do not believe the Government has sufficient funds at its disposal to engage men to patrol such an area, and as

(b) persons are so involved in the capture of orang-utans for smuggling out of Indonesia, and as

(c) the estimated population of orang-utans in the above area is possibly only about 1,000 animals, and

(d) in view of the fact that at a recent meeting of the American Association of Zoological Parks and Aquariums the following motion was passed :-

"A list of animals to be prepared, whose wild populations would be 
severely endangered by new zoo collection, importation, and/or exhibition; that this list, after annual review and approval by the board of the AAZPA be published as the "AAZPA Black List" and that members be encouraged to support a policy of non-exhibition of such endangered forms" (with special reference to orang-utans).

I would like to recommend that :-

(1) The Indonesian Government requests its highest authority to take urgent and very strong steps to condemn and prevent the smuggling of orang-utans from Indonesia.

(2) Local Forest Department, Wildlife Conservation, and Customs officials have the authority to arrange for surprise check points along the road leading from the Loser complex to Medan and ports from which vessels might leave for Singapore, Malaya, Thailand, etc.

(3) They have the authority to confiscate any illegally owned orang-utan and ensure that the owner is severely fined.

(4) Frequent checks are made by Customs officials at all airports as many orang-utans are smuggled out by plane.

(5) The Customs, Veterinary, and other appropriate Departments in Singapore in particular, but also in other ports such as Bangkok and Hong Kong, be requested to co-operate in a general campaign to end the smuggling of orang-utans from Indonesia.

(6) Until such time as an effectively patrolled sanctuary or special reserve is formed the IUCN assist the Indonesian Government in finding means of disposing of those orang-utans confiscated and already known to be in illegal captivity (such as the approximately forty-five specimens in the general vicinity of Medan in March 1963).

(7) Any of these forty-five specimens which have not already died be sold possibly at a nominal price to approved zoos.

(8) Funds from outside sources be made available to the Indonesian Government to assist them in developing a special reserve in the Loser region.

(9) A further study be made of the Loser complex in the near future to determine a suitable area for a special reserve.

Photographs of orang-utans in captivity and of the habitat, taken by Oliver Milton on this survey expedition, are on Plates 3-6, following page 172 .

\section{Successful Leathery Turtle Hatch}

At the leathery turtle hatchery at Rantau Abang in Malaya last summer, 56 per cent of the eggs hatched as compared with 54 per cent in 1954 and 44 per cent in 1961. Starting in June, 9,956 eggs from 112 nests were transplanted into the hatchery, and the first egg hatched in August. Apart from 210 that died, all the baby turtles were released at sea before the end of October, being taken some distance off shore to minimise losses by natural predators. The work is now carried out under the direction of the Fisheries Department. An article on the leathery turtle and the hatchery appeared in OrYX, Vol. VI, August, 1961. 